African Crop Science Journal by African Crop Science Society is licensed under a Creative Commons Attribution 3.0 Uganda License. Based on a work at www.ajol.info/ and www.bioline.org.br/cs DOI: $\underline{\text { https://dx.doi.org/10.4314/acsj.v27i1.2 }}$

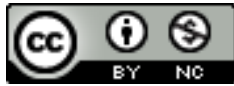

\title{
PERFORMANCE AND INHERITANCE OF YIELD AND MAIZE STREAK VIRUS DISEASE RESISTANCE IN WHITE MAIZE AND YELLOW CONVERSIONS
}

\author{
G. NKURUNZIZA ${ }^{1,2}$, G. ASEA ${ }^{3}$, D.B. KWEMOI ${ }^{3}$ and P. WASSWA ${ }^{1}$ \\ ${ }^{1}$ Department of Agricultural Production, Makerere University, P. O. Box 7062, Kampala, Uganda \\ ${ }^{2}$ Institut des Sciences Agronomiques du Burundi, ISABU, B.P. 795 Bujumbura, Burundi \\ ${ }^{3}$ National Crop Resources Research Institute, NARO, P. O. Box 7084, Kampala, Uganda \\ Corresponding author: nkurugelase@gmail.com
}

(Received 28 June,2018; accepted 20 February, 2019)

\begin{abstract}
In sub Saharan Africa, past effort has registered success in developing high yielding and foliar disease resistant maize (Zea mays L.) varieties, which are deficient in pro-vitamin A. A new initiative is to develop maize varieties, tolerant to foliar diseases and rich in pro-vitamin A carotenoids. To achieve this, yellow conversions of white testers and other elite maize varieties have been developed by the International Center for Maize and Wheat Development (CIMMYT). Unlike the white lines, limited information on agronomic performance and disease resistance is available for yellow maize conversions. This study was conducted to evaluate the performance of white maize and their corresponding yellow maize conversions for yield and tolerance to Maize streak virus (MSV) disease; and determine the inheritance patterns of these traits. Fourty seven three-way hybrids generated in a Line by tester mating design (North Carolina 2), 12 inbred lines (used as male parents), 4 single crosses (used as female parents) and 3 commercials checks were screened for resistance to Maize streak virus (MSV) disease at the National Crop Resources Research Institute (NaCRRI) in Uganda. The same genotypes were evaluated in a 9x5 alpha lattice design in three locations of Uganda (National Crop Resources Research Institute (NACRRI), National Semi Arid Resources Research Institute (NaSARRI) and Bulambuli) for agronomic performance. Results confirmed tolerance to MSV in testers CML202, CML395, CML444, CML445 and CML312-SR (white). Genotypes performed significantly differently for yield, anthesis days, plant height, ear height, husk cover, grain texture, reaction to Gray leaf spot $(\mathrm{GLS})(\mathrm{P}<0.001)$ and ear aspect $(\mathrm{P}<0.01)$. However, pairwise comparison of white and yellow conversions indicated no significant difference $(\mathrm{P}>0.05)$ in agronomic performance and tolerance to diseases. General combining ability (GCA) was more important than specific combining ability (SCA) for most traits, except for anthesis days, Turcicum leaf blight (TLB), GLS and yield. GCA effects for yield were not significant in both lines (male parents) and single cross testers (female parents) of white and yellow conversions. However, two unique cases were observed for diseases; yellow conversion of line CML444 significantly combined for susceptibility to TLB; while tester CML312/CML442 combined for resistance to GLS. Additionally, there was low heritably estimates for tolerance to MSV and yield.
\end{abstract}


Generally, there was no significant difference between white and corresponding yellow maize conversion, implying that there is no significant loss in MSV resistance and yield performance while converting white into yellow maize.

Key Words: Combining ability, pro-vitamin A, Zea mays L.

\section{RÉSUMÉ}

En Afrique sub-Saharienne, les efforts antérieurs ont connu de grands succès dans le développement des variétés très productives et tolérantes aux maladies foliaires du maïs (Zea mays L.), mais qui sont pauvres en provitamine A. La nouvelle vision est de développer des variétés de maïs résistantes aux principales maladies foliaires, et riche en caroténoïdes provitamine A. Pour y arriver, les conversions jaunes issues des testeurs blancs de maïs ainsi que les variétés élite ont été développées par le Centre International pour l'Amélioration du Maïs et du Blé (CIMMYT). Contrairement aux lignées blanches de maïs, la performance agronomique et le niveau de résistance aux maladies des lignées jaunes reste méconnue. Cette étude a été menée dans le but d'évaluer la performance au niveau du rendement et la résistance à la maladie des bandes (MSV) des variétés de maïs à grain de couleur blanche et leurs conversions de couleur jaune et déterminer le mode d'héritabilité de ces deux paramètres étudiés. Quarante-sept hybrides trois voies produits dans un mode de croisement Lignée par testeur (North Carolina II), 12 lignées épurées (utilisées comme parents mâles), 4 hybrides simples (utilisés comme parents femelles) et 3 témoins ont été inoculés par l'agent causal de la maladie des bandes à NaCRRI (National Crop Ressources Research Institute) en Ouganda. La performance agronomique des mêmes génotypes a été évaluée dans un dispositif expérimental d'alpha lattice (5parcelles élémentaires x 9 blocks) dans 3 sites de l'Ouganda à savoir NaCRRI (National Crop Ressources Research Institute), NaSARRI (National Semi Arid Resources Research Institute) et Bulambuli. Les résultats ont confirmé la tolérance à la MSV des testeurs à grains blancs CML202, CML395, CML444, CML445 et CML 312SR. La performance des génotypes était hautement significativement différente pour le rendement, le nombre de jours de floraison mâle, la hauteur des plants, le niveau d'insertion des épis sur les plants, la couverture des épis par les spathes, la texture des grains, la réaction à la GLS (Glay leaf spot) $(\mathrm{P}<0.001)$ ainsi que pour l'aspect des épis $(\mathrm{P}<0.01)$. Cependant, la comparaison entre le maïs blanc et sa conversion jaune a montré une différence non significative $(\mathrm{P}>0.05)$ au niveau de leur performance agronomique et la tolérance aux maladies. L'aptitude générale à la combinaison (GCA) était plus importante que l'aptitude spécifique à la combinaison (SCA) pour la plupart des paramètres à l'exception du nombre de jours à floraison mâle, la tolérance à l'helminthosporiose (TLB), GLS et le rendement. Les effets dus à la GCA pour le rendement n'étaient pas significatifs pour les parents mâles (lignées) et femelles (hybrides simples) des génotypes à grain de couleur blanche et leurs conversions à grain de couleur jaune. Néanmoins, deux cas exceptionnels ont été observés pour la tolérance aux maladies: la conversion jaune de la lignée CML444 était un mauvais combinateur pour la TLB, alors que le testeur CML312/CML442 combinait bien pour la tolérance à la GLS. En plus, l'héritabilité était faible pour la tolérance à la MSV et le rendement. En général, il n'y avait pas de différence significative entre les génotypes à grain blanc et leurs conversions jaunes respectives, ce qui signifie que, lors de la conversion des variétés à grain blanc en variétés à grain jaune, il n'y a aucune perte significative en ce qui est de la tolérance à la MSV et la performance en rendement des grains.

Mots Clés : Aptititude à la combinaison, pro-vitamine A, Zea mays L. 


\section{INTRODUCTION}

Maize (Zea mays L.) is one of the most important and widely grown cereal crops in East Africa. Its popularity is attributed to its ability to grow in a wide range of environments, high grain yield per unit area and palatability. The crop is cultivated by about 86 percent of the 4.2 million agricultural households in Uganda (Okoboi et al., 2012) and in 2012 for instance, maize occupied $62.6 \%$ of total area planted with cereals (UBOS, 2013).

Maize production is challenged by foliar diseases, especially Maize streak virus (MSV) disease; which is reportedly the most widespread disease of maize in sub-Saharan Africa (Bosque-Pérez, 2000; Mawere et al., 2006). MSV can decrease yield by up to $71 \%$ (Nilsa et al., 1998). Breeding for MSV resistance has resulted in identification of genes of resistance in line CML202 (Welz et al., 1998). This inbred line has been used in crossing with other inbred lines for developing new MSV resistant varieties of maize. Given the importance of the disease, developing maize genotypes resistant to the causal agent is a priority (Mawere et al., 2006; Awata, 2012).

Yellow and orange maize varieties are richer in pro-vitamin A, compared to the white maize; but their status of MSV resistance in Uganda is not documented. Yellow and orange maize can be obtained by converting white maize, and vice versa, using backcross selection (Kristin et al., 2013; Kandianis et al., 2013). Uganda has largely been a white maize market. However, the white maize is low in pro-vitamin A content, compared to the yellow and orange one. Since Ugandans consume a lot of maize more than other source of Vitamin A, it will be better to increase the content of vitamin $\mathrm{A}$ in maize from, which they can get it; and therefore, contribute to fight against the malnutrition due to vitamin A deficiency (VAD) (Liu et al., 2015).
Single cross testers (white and corresponding yellow conversions) developed by the International Center for Maize and Wheat Development (CIMMYT) are available in Uganda, but the way they may transmit the MSV resistance and the yield performance in the progenies have hitherto not been documented. This study investigated the performance of white maize and their corresponding yellow maize conversions in terms of yield and tolerance to MSV disease as well as MSV and yield inheritance patterns.

\section{MATERIALS AND METHODS}

Twelve inbred lines ( 6 white and 6 yellow) and 4 testers ( 2 white and 2 yellow) obtained from the International Center for Maize and Wheat Development (CIMMYT) were used in this study as parental materials. The germplasm varied in heterotic groups and colour (Table 1).

A line by tester cross was made among the twelve male lines and four female single-cross testers, forming 47 three way hybrids (one was not successful). Those 47 three way hybrids were evaluated together with the 4 single-cross testers and 3 hybrids checks, making in total 54 entries. The evaluation was carried out in three locations, Namulonge, Serere and Bulambuli in Uganda (Table 2).

Treatments were arranged in a 9x6 alpha lattice design, replicated twice, during the first rainy season of 2015 (April-August). Seeds were planted in a two-row plot of $5 \mathrm{~m}$ long, with a spacing of $75 \mathrm{~cm} \times 25 \mathrm{~cm}$, giving a plant density of 53,000 plants ha-1. Uniform agronomic practices (e.g. no organic fertilisation, application of chemical against stem borers and weeding) were observed in all locations.

For each plot, the following traits were recorded: silking days (SD), as the number of days from planting to when $50 \%$ of the plants had emerged silks; and anthesis days (AD), when $50 \%$ had shed pollen. The anthesis- 
TABLE 1. Maize germplasm used and their attributes

\begin{tabular}{lllll}
\hline Name & Pedigree & Origin & Colour & $\begin{array}{l}\text { Heterotic } \\
\text { group }\end{array}$ \\
\hline CML445 & CML445 & & AB \\
CML445Y & CML445Y & CIMMYT & White & AB \\
CKL05003 & CKL05003 & CIMMYT & Yellow & B \\
ZM523A-16-2-1-1-B*5-B-B & ZM523A-16-2-1-1-B*5-B-B & CIMMYT & White A & \\
CKDHL0159 & CKDHL0159 & CIMMYT & White & - \\
CKDHL0500 & CKDHL0500 & CIMMYT & White & - \\
CLRC034 & CLRC034 & CIMMYT & Yellow & - \\
DTPCY9-F46-1-2-1-2-8Y & DTPCY9-F46-1-2-1-2-8 & CIMMYT & Yellow & - \\
CLYN261 & CLYN261 & CIMMYT & Yellow & - \\
CML444 & CML444 & CIMMYT & White & B \\
CML444Y & CML444Y & CIMMYT & Yellow & B \\
CML451Y & CML451 & CIMMYT & Yellow & B \\
CML202/CML395 & CML202/CML395 & CIMMYT & White & Tester B \\
CML312/CML442 & CML312/CML442 & CIMMYT & White & Tester A \\
CML202Y/CML395Y & CML202Y/CML395Y & CIMMYT & Yellow & Tester B1 \\
CML312Y/CML442Y & CML312Y/CML442Y & CIMMYT & Yellow & Tester A1 \\
\hline
\end{tabular}

TABLE 2. Geographical characteristics of the three locations used for hybrid evaluation

\begin{tabular}{llcccc}
\hline Site & Location & Altitude $(\mathrm{m})$ & \multicolumn{2}{c}{ Average temperature $\left({ }^{\circ} \mathrm{C}\right)$} & $\begin{array}{c}\text { Annual } \\
\text { rainfall (mm) }\end{array}$ \\
\hline NaCRRI & Namulonge & 1150 & Minimum & Maximum & \\
NaSARRI & Serere & 1080 & 15.5 & 28.1 & 1300 \\
Bulambuli & Bulambuli & 1060 & 18.5 & 28.1 & 1427 \\
\hline
\end{tabular}

Source: Ministry of Water and Energy; Meteorology Department, Kampala, Uganda, 2012. NaCRR I = National Crop Resources Research Institute, NaSARRI = National semi arid Resources Research Institute

silking interval (ASI) was computed as the difference between days to silking and anthesis. Plant height $(\mathrm{PH})$ was measured as the distance from the base of the plant to the height of the first tassel branch and ear height $(\mathrm{EH})$ as the distance from the base to the node bearing the upper ear. Grain texture was scored using a $1-5$ rating scale, where $1=$ flint: round-crown kernel with vitreous appearance and $5=$ dent: kernel dented and having a floury endosperm (Batr'an et al., 2002; Melanie,
2006). Ears were harvested from each plot and shelled to determine the percentage grain moisture. Grain yield was determined at harvest from cob fresh weigh adjusted at $12.5 \%$ moisture content and converted to tons per hectare. The shelling percentage was estimated at $80 \%$.

Disease severity was also measured using the $1-5$ rating scale; where $1=$ without symptom of the disease and $5=$ the whole plant is devastated by the disease (Tefera et al., 
2011). The following diseases were evaluated: MSV, Glay leaf spot (GLS), Common rust and Tulcicum leaf blight (TLB).

Screening of resistance to MSV. All materials including, inbred lines (male parents), single cross testers (female parents) as well as the three way hybrids generated were inoculated with MSV. Diseased plants were collected in the farmer's field neighbouring Namulonge, and used as source of inoculum. The diseased plants were placed in cages and leafhoppers of the family cicadellidea introduced and fed on diseased plants; 3 days before inoculating healthy plants. For each entry (genotype) 22 seeds were planted in 2 replicates, 2 seeds per box and inoculated after 14 days. The inoculation consisted of placing maize plants into cages that contained leafhoppers, previously fed on diseased plants. These leafhoppers were allowed 48 to 72 hours access period. Infected plants were transplanted into the field in rows of $3 \mathrm{~m}$ wide and $25 \mathrm{~cm}$ between holes. Plants were thinned to one plant per hole after seedling establishment.

\section{Statistical analysis}

Screening of resistance to MSV. MSV disease severity was scored three times 14 days after inoculation, and an average score was calculated for each genotype per plot. Data obtained from each type of disease assessment were analysed separately using Restricted Maximum Likelihood (ReML) as implemented in GenStat $12^{\text {th }}$ Edition (VSN International Ltd., UK) for Analysis of Variance (ANOVA). The three ways cross hybrids made from a given conversion were analysed separately to study the conversion effect on MSV resistance.

Multi-location evaluation. The data collected from the fields about yield and MSV status, as well as other important agronomic traits such as anthesis days, silking days, plant height, ear height, ear texture were analysed with GenStat $12^{\text {th }}$ Edition (VSN International Ltd., UK) for Analysis of Variance (ANOVA). Data from evaluation trials were performed across sites using a ReML option of GenStat, considering genotype as fixed effects and location, replications and blocks within replications as random effects. The statistical model of Lattice Incomplete Block Analysis, with adjusted treatment means, was followed during data analysis. Analysis of variance was performed for all the traits.

In case where the lattice blocks were not effective, analysis was done using the randomised complete block design. The multiple comparison was done using Fisher's Protected Least Significant Difference (LSD) test at $\mathrm{P}<0.05$.

Combining ability for the line by tester across location was analysed using genotype means from each site as input data, following the linear model:

$\bar{Y}_{i j}=m+g_{i}+g_{j}+s_{i j}+\bar{e}_{i j}$

Where:

$\bar{Y}_{i j}$ is the mean value of hybrid $i j(i, j=1,2$, $\ldots p, i<j) ; m$ is the general mean of the segregating populations; $g_{i}$ and $g_{j}$ are the general combining ability effects of the $i^{\text {th }}$ and $\mathrm{j}^{\text {th }}$ parents, respectively; $\mathrm{s}_{\mathrm{ij}}$ is the specific combining ability effect of the $\mathrm{ij}^{\text {th }}$ cross, and $\overline{\mathrm{e}}_{\mathrm{ij}}$ is the error associated with the $\mathrm{ij}^{\text {th }}$ observation.

The relative importance of GCA and SCA was evaluated using a ratio of variance components, calculated as $2 \delta^{2} \mathrm{GCA} /$ $\left(2 \delta^{2} \mathrm{GCA}+\delta^{2} \mathrm{SCA}\right)$, as recommended by Baker (1978); and hereafter, referred to as "Baker's ratio" (Baker, 1978; Teklewold and Becker, 2005).

The linear mathematical model for the pooled analyses of variance of genotypes across locations was: 


$$
Y_{i j k}=\overline{\bar{Y}}+G_{i}+L_{j}+G_{i} x L_{j}+R / L_{j k}+e_{i j k}
$$

Where:

$\overline{\bar{Y}}$ is the grand mean of the experiment, $G_{i}$ is genotype mean effect, $L_{j}$ Location mean effect, $G_{i} x L_{j}$.

The three way cross hybrids genotype by location interaction effect, $R / L_{j k}$ replications within location effect and $e_{i j k}$ the experimental error made from a given conversion parents were analysed separately to study the conversion effect on grain yield.

Across location, the heritability estimates on plot and entry mean bases were determined according to the formulas below (Alan and Geren, 2007; Awata, 2012). Heritability on entry mean basis was referred to as broad sense heritability (H2) and calculated on entry mean across site basis and was referred to as broad sense coefficient of genetic determination (BS-CGD):

BS-CGD $=\left(2 \sigma^{2}{ }_{\mathrm{GCA}}+\sigma^{2}{ }_{\mathrm{SCA}}\right) /\left(2 \sigma_{\mathrm{GCA}}^{2}+\right.$ $\left.\sigma_{\mathrm{SCA}}^{2}+2 \sigma_{\mathrm{GCAXE}}^{2} / \mathrm{E}+\sigma_{\mathrm{SCAxE}}^{2} / \mathrm{E}+\sigma^{2} \varepsilon / \mathrm{rE}\right)$

Heritability on plot basis was referred to as narrow sense heritability and calculated as narrow sense coefficient of genetic determination (NS-CGD):

NS-CGD $=2 \sigma^{2}$
$+2 \sigma^{2}{ }_{\mathrm{GCA}} / \quad\left(2 \sigma^{2}{ }_{\mathrm{GCA}}+\sigma^{2}{ }_{\mathrm{SCA}}\right.$

Where:

$\mathrm{E}=$ number of environments, $\mathrm{r}=$ number of replications.

\section{RESULTS}

Line by Tester analysis of variance (Table 3) showed that environments were significantly $(\mathrm{P}<0.001)$ different for all the traits studied.
Across location, the male parents varied highly significantly $(\mathrm{P}<0.01)$ for yield and significantly $(\mathrm{P}<0.05)$ for anthesis-silking interval and GLS resistance while they did not vary $(\mathrm{P}>0.05)$ for anthesis days, MSV, TLB and rust. Similarly, male parents $\mathrm{x}$ environment interaction was highly significantly different $(\mathrm{P}<0.001)$ for anthesis days, anthesis-silking interval, yield, MSV, GLS and rust resistance and non-significant $(\mathrm{P}<0.05)$ for TLB resistance. For female parents, the analysis showed a non-significant $(\mathrm{P}<0.05)$ difference for all traits studied. However, the female parents $\mathrm{x}$ environment interaction was significant $(\mathrm{P}<0.05)$ for anthesis days, anthesis-silking interval and very highly significant $(\mathrm{P}<0.001)$ for MSV. However, it was not significant $(\mathrm{P}>0.05)$ for TLB, significant $(\mathrm{P}<0.05)$ for GLS, very highly significant $(\mathrm{P}<0.001)$ for rust resistance and yield. Likewise, across location, the three way cross hybrids were highly significantly different $(\mathrm{P}<0.001)$ for anthesis days and anthesis-silking interval, slightly significant $(\mathrm{P}<0.05)$ for MSV, not significant $(\mathrm{P}>0.05)$ for TLB and highly significant for GLS, rust and yield. The interaction between crosses $\mathrm{x}$ environment $(\mathrm{GxE})$ interaction was highly significantly different $(\mathrm{P}<0.001)$ for all the traits except for TLB resistance.

Baker's ratio due to GCA and SCA across location varied and ranged from 0.11 for TLB and 1.0 for MSV and anthesis-silking interval (ASI) (because of one of the expected mean squares for female or male was negative and thus assumed to zero) (Table 3). The broad sense coefficient of genetic determination value ranged from 0.03 for MSV and 0.31 for grain yield. Narrow sense coefficient of genetic determination values varied from 0.008 for TLB to 0.15 for grain yield (Table 3 ).

Three lines, CML312-SR, CML395 and CML444 (white), showed a high tolerance to MSV (score <2); while 3 other lines (CML444 yellow, CML445 yellow and DTPYC9-F461-2-1-2-BY) were more susceptible (score $>3$ ) than others (Table 4). Lines CKDHL019, CLYN261Y and CML395 were high yielding; 
TABLE 3. Across location analysis (NaCRRI, NaSARRI and Bulambuli in Uganda) of combining ability for yield and other agronomic traits of maize

\begin{tabular}{|c|c|c|c|c|c|c|c|c|}
\hline \multirow{2}{*}{$\begin{array}{l}\text { Source of } \\
\text { variation }\end{array}$} & \multirow[t]{2}{*}{ d. f. } & \multicolumn{7}{|c|}{ Mean square } \\
\hline & & $\begin{array}{l}\text { AD } \\
\text { (days) }\end{array}$ & $\begin{array}{l}\text { ASI } \\
\text { (days) }\end{array}$ & $\begin{array}{l}\text { MSV } \\
(1-5)\end{array}$ & $\begin{array}{l}\text { TLB } \\
(1-5)\end{array}$ & $\begin{array}{l}\text { GLS } \\
(1-5)\end{array}$ & $\begin{array}{l}\text { Rust } \\
\text { (1-5) }\end{array}$ & $\begin{array}{l}\text { Yield } \\
\left(\mathrm{t} \mathrm{ha}^{-1}\right)\end{array}$ \\
\hline Envir.(E) & 2 & $689.1 * * *$ & $9.96 * * *$ & $0.24 * * *$ & $6.21 * * *$ & $2.74 * * *$ & $4.77 * * *$ & $91.45 * * *$ \\
\hline Male (M) & 11 & 18.24 & $2.27 *$ & 0.07 & 0.18 & $0.08^{*}$ & 0.21 & $3.69 * *$ \\
\hline MxE & 22 & $16.03 * * *$ & $0.75^{* * *}$ & $0.04 * * *$ & 0.16 & $0.03^{* * *}$ & $0.18 * * *$ & $1.14 * * *$ \\
\hline Female(F) & 3 & 19.543 & 1.77 & 0.09 & 0.19 & 0.02 & 0.39 & 10.221 \\
\hline $\mathrm{F} \times \mathrm{E}$ & 6 & $4.76^{*}$ & $0.82^{*}$ & $0.18 * * *$ & 0.27 & $0.03^{*}$ & $0.27 * * *$ & $2.38 * * *$ \\
\hline $\mathrm{M} \times \mathrm{F}$ & 32 & $8.62 * * *$ & $0.76^{* * *}$ & $0.03 *$ & 0.17 & $0.07 * * *$ & $0.12 * * *$ & $2.63^{* * *}$ \\
\hline M xFxE & 64 & $5.22 * * *$ & $0.76 * * *$ & $0.05 * * *$ & 0.12 & $0.03 * * *$ & $0.11 * * *$ & $1.26 * * *$ \\
\hline Error & & 1.73 & 0.27 & 0.02 & 0.55 & 0.01 & 0.04 & 0.30 \\
\hline Error d.f. & & 93 & 78 & 159 & 38 & 49 & 94 & 79 \\
\hline$\delta^{2} \mathrm{E}$ & & 7.160 & 0.101 & 0.002 & 0.064 & 0.028 & 0.049 & 0.949 \\
\hline$\delta^{2} \mathrm{M}$ & & 0.092 & 0.063 & 0.001 & 0.001 & 0.002 & 0.001 & 0.106 \\
\hline$\delta^{2} \mathrm{MxE}$ & & 1.788 & 0.059 & 0.002 & 0.015 & 0.003 & 0.017 & 0.105 \\
\hline$\delta^{2} \mathrm{~F}$ & & 0.205 & 0.013 & -0.001 & 0.000 & 0.000 & 0.002 & 0.109 \\
\hline$\delta^{2} \mathrm{FxE}$ & & 0.126 & 0.023 & 0.007 & 0.009 & 0.001 & 0.010 & 0.087 \\
\hline$\delta^{2} \mathrm{MxF}$ & & 0.567 & 0.000 & -0.004 & 0.008 & 0.005 & 0.003 & 0.228 \\
\hline$\delta^{2} \mathrm{MxFxE}$ & & 1.745 & 0.245 & 0.017 & 0.041 & 0.012 & 0.033 & 0.482 \\
\hline $\mathrm{BR}$ & & 0.344 & 1.000 & 1.000 & 0.112 & 0.265 & 0.501 & 0.486 \\
\hline BS-CGD & & 0.138 & 0.113 & 0.030 & 0.074 & 0.217 & 0.055 & 0.313 \\
\hline NS-CGD & & 0.048 & 0.113 & 0.030 & 0.008 & 0.058 & 0.027 & 0.152 \\
\hline
\end{tabular}

*** Significantly different at $\mathrm{P}<0.001$, **significantly different at $\mathrm{P}<0.01$, * significantly different at $\mathrm{P}<0.05$, ns $=$ not significantly different $(\mathrm{P}>0.05) . \mathrm{BR}=$ Baker's ratio, NS-CGD $=$ narrow sense-coefficient of genetic determination, $\mathrm{BS}-\mathrm{CGD}=$ broad sense-coefficient of genetic determination. $\mathrm{AD}=$ Anthesis days, $\mathrm{ASI}=$ AnthesisSilking interval, MSV = maize streak virus disease, TLB = Turcicum leaf blight, GLS = Glay leaf sport

while CML444Y and CML451Y were less yielding (Table 5).

For the three way hybrids, the mean of yield was $5.81 \mathrm{t} \mathrm{ha}^{-1}$, average MSV severity was 2.82; while mean GLS, TLB and rust severities were $1.72,1.73$ and 1.67 , respectively (Table 6).

Conversions in terms of yield and resistance to MSV. Yield and MSV resistance among the 4 testers analysed as conversions were not significantly $(\mathrm{P}<0.05)$ different (Table 7). The hybrids were analysed separately according to the conversion testers from which they were made (i.e., CML202/ CML395 versus CML202Y/CML395Y and CML312/CML442 versus CML312Y/ CML442Y). It was observed that the three way hybrids generated from corresponding conversions did not significantly $(\mathrm{P}<0.05)$ differ in terms of MSV resistance and grain yield performance (Table 8).

\section{Conversions in terms of grain yield and} other traits. Comparison between the three way hybrids, based on their testers female parents for yield, MSV severity and other agronomic traits, revealed that within conversions, the white and corresponding yellow tester conversions performed almost similarly for all the traits studied, except for MSV resistance in CML312/CML442 versus CML312Y/CML442Y, ear height in CML202/ CML395 versus CML202Y/CML395Y and plant height in both conversions CML202/ CML395 versus CML202Y/CML395Y and 
TABLE 4. Means for MSV incidence and severity, TLB and GLS scoring of maize inbred lines during the screening at NaCRRI in Uganda

\begin{tabular}{|c|c|c|c|c|}
\hline \multirow[t]{2}{*}{ Lines } & \multicolumn{4}{|c|}{ Mean } \\
\hline & MSV Inc (\%) & MSV Sev. (1-5) & TLB sev. (1-5) & GLS sev.(1-5) \\
\hline CKDHL0159 & 24.88 & 2.37 & 1.64 & 1.83 \\
\hline CKDHL0500 & 29.49 & 2.99 & 1.29 & 1.83 \\
\hline CKL05003 & 22.12 & 2.49 & 1.69 & 1.67 \\
\hline CLRCY034Y & 33.52 & 2.93 & 1.55 & 1.50 \\
\hline CLYN261Y & 24.70 & 2.40 & 1.41 & 1.33 \\
\hline CML202 & 24.70 & 2.31 & 1.49 & 2.67 \\
\hline CML202Y & 30.03 & 2.70 & 1.40 & 1.50 \\
\hline CML312 & 21.06 & 3.05 & 1.33 & 1.50 \\
\hline CML312-SR & 10.08 & 2.00 & 1.55 & 2.33 \\
\hline CML312Y & 18.90 & 2.42 & 1.46 & 1.83 \\
\hline CML395 & 17.39 & 2.38 & 1.70 & 2.00 \\
\hline CML395Y & 9.93 & 1.85 & 1.50 & 2.00 \\
\hline CML442 & 19.05 & 2.42 & 1.60 & 1.50 \\
\hline CML442Y & 17.29 & 2.24 & 1.35 & 1.67 \\
\hline CML444 & 15.16 & 1.91 & 1.65 & 2.17 \\
\hline CML444Y & 35.22 & 3.31 & 1.52 & 1.67 \\
\hline CML445 & 14.03 & 2.02 & 1.99 & 1.50 \\
\hline CML445Y & 32.62 & 3.01 & 1.68 & 1.83 \\
\hline CML451Y & 30.30 & 2.83 & 1.20 & 1.67 \\
\hline DTPYC9-F46-1-2-1-2-BY & 43.58 & 3.68 & 1.64 & 1.00 \\
\hline ZM523AA-16-2-1-1-B*5-B-B & 22.15 & 2.37 & 1.84 & 1.33 \\
\hline Check (CML300) & 25.98 & 2.81 & 1.69 & 1.67 \\
\hline Grand mean & 23.74 & 2.58 & 1.55 & 1.73 \\
\hline $\operatorname{LSD}(\mathrm{P}<0.05)$ & 26.02 & 1.64 & 0.66 & 0.72 \\
\hline $\mathrm{CV}(\%)$ & 49.20 & 30.60 & 20.00 & 20.20 \\
\hline
\end{tabular}

CML312/CML442 versus CML312Y/ CML442Y (Table 9).

Single cross tester CML312/CML442 had a good general combining ability (GCA); while CML202Y/CML395Y had a poor GCA for grain yield (Table 9). Among male parents, line CML444 had the best GCA effects; while CKL05003 had the poorest GCA (Table 10). Likewise, the pure white crosses such asCML312/CML442//ZM523A-16 and CML312/CML442//CKDHL0159; the pure yellow crosses CML202/CML395// CKDHL0500 and CML312/CML442// CLRC034; and the mixed crosses CML202/
CML395//CML451Y, CML312/CML442// DTPCY9-46 had good SCA for grain yield. On the other hand, the crosses such as CML202/CML395//ZM523A-16, CML202Y/ CML395Y//CLYN261 (yellow), CML312/ CML442//CKDHL0500 (white), CML312/ CML442//CLRC034 (mixed) and CML312Y/ CML442Y//DTPCY9-46 (yellow) had a poor SCA for grain yield (Table 10).

\section{DISCUSSION}

Heritability for yield and MSV resistance. The estimated heritability was low for all the 
TABLE 5. Yield and MSV severity scoring of maize inbred lines during the evaluation across 2 locations in Uganda

\begin{tabular}{|c|c|c|}
\hline \multirow[t]{2}{*}{ Lines } & \multicolumn{2}{|c|}{$\begin{array}{l}\text { Evaluation across } \\
2 \text { sites (Namulonge } \\
\text { and Serere) }\end{array}$} \\
\hline & $\begin{array}{r}\text { Yield } \\
\left(\mathrm{t} \mathrm{ha}^{-1}\right)\end{array}$ & $\begin{array}{c}\text { MSV } \\
\text { Sev. (1-5) }\end{array}$ \\
\hline CKDHL0159 & 4.09 & 1.45 \\
\hline CKDHL0500 & 2.91 & 0.48 \\
\hline CKL05003 & 3.37 & 0.82 \\
\hline CLRCY034Y & 2.92 & 0.93 \\
\hline CLYN261Y & 3.72 & 0.81 \\
\hline CML202 & 2.32 & 0.85 \\
\hline CML202Y & 2.36 & 1.42 \\
\hline CML312 & 2.42 & 2.15 \\
\hline CML312-SR & 3.40 & 0.90 \\
\hline CML312Y & 3.64 & 0.81 \\
\hline CML395 & 3.97 & 1.27 \\
\hline CML395Y & 3.25 & 1.13 \\
\hline CML442 & 2.90 & 0.76 \\
\hline CML442Y & 3.60 & 0.73 \\
\hline CML444 & 3.49 & 1.09 \\
\hline CML444Y & 1.22 & 1.45 \\
\hline CML445 & 2.37 & 1.84 \\
\hline CML445Y & 3.08 & 1.60 \\
\hline CML451Y & 1.78 & 1.34 \\
\hline DTPYC9-F46-1-2-1-2-BY & 2.27 & 1.26 \\
\hline ZM523AA-16-2-1-1-B*5-B-B & 2.72 & 0.92 \\
\hline $\operatorname{check}(\mathrm{CML} 300)$ & 2.78 & 1.11 \\
\hline Grand mean & 2.93 & 1.14 \\
\hline $\operatorname{LSD}(\mathrm{P}<0.05)$ & 1.54 & 0.41 \\
\hline $\mathrm{CV}(\%)$ & 26.46 & 24.84 \\
\hline
\end{tabular}

trait studied: anthesis days (narrow sense, $4 \%$,), anthesis-silking interval (narrow sense, $11.3 \%$,$) , MSV (3\%), TLB (0.8 \%)$, GLS (5\%), rust $2.7 \%$ and yield $(15.2 \%$ ) (Table 3 ). The narrow sense heritability could be explained by the high variation between the environments causing high error term. Thus, for quantitative traits such as yield, with low heritability, many crosses or many generations are required to transmit the trait from parents to the progenies.
This result is consistent with results found by other researchers, such as Ünay et al. (2004) (23\%), Wannows et al. (2010) (39\%) and Olakojo and Olaoye (2011) (19\%) who found yield low heritable in their respective studies. However, our findings disagree with those of Awata (2012) who found that yield was moderately heritable, and those of Gichuru et al. (2011) and Aminu and Izge (2012), whose results showed a high heritability for this same trait.

Likewise, the low heritability estimates found for MSV resistance could be explained by the heterotic group of the germplasm used. For this particular population used, more crosses and late generation are required to transmit the resistance to MSV from parents to progenies. These results do not agree with the findings of Efron et al. (1989), Welz et al. (1998) and Gichuru (2013), whose results showed a high heritability for this trait.

Combining ability. The GCA components were more important than SCA, for most traits because the Baker's ratio was close to 1.0 (Olfati et al., 2012). This suggests that out of the total genetic variation observed, additive genetic effects were more important than nonadditive effects in the inheritance of most of the traits except the grain yield and MSV resistance. Gichuru et al. (2011) reported similar patterns in their work on combining ability for grain yield and Agronomic traits among diverse MSV resistance maize lines in the Eastern Africa region. Screening for MSV resistance of both single cross testers and the inbred lines revealed non-significant GCA mean square (Table 10). This result implies that the germplasm used had practically the same ability of transmitting tolerance to MSV to their progenies, since the single crosses used were all released in Uganda where the MSV tolerance was one of the characteristics of these particular genotypes. Similarly, in the three way crosses, all the parents showed a non-significant GCA for MSV resistance. This means the selection for MSV tolerance cannot 
TABLE 6. Selected best hybrids and worst hybrids for both yield and MSV severity in maize

\begin{tabular}{llcc}
\hline Entry & Genotypes & Yield & MSV severity \\
\hline 10 & CML202Y/CML395Y/CKDHL0500 & 6.07 & 2.14 \\
21 & CML312Y/CML442Y/CKDHL0159 & 7.06 & 1.93 \\
22 & CML312Y/CML442Y/CKDHL0500 & 6.10 & 1.28 \\
27 & CML202/CML395/CLYN261 & 7.26 & 2.41 \\
34 & CML202/CML395/CKDHL0500 & 5.50 & 2.10 \\
35 & CML202/CML395/CML444 & 6.33 & 1.92 \\
37 & CML312/CML442/CLRC034 & 7.68 & 2.87 \\
43 & CML312/CML442/CKL05003 & 6.63 & 2.30 \\
47 & CML312/CML442/CML444 & 7.09 & 4.03 \\
53 & LONGE10(Check1) & 4.67 & 2.11 \\
3 & CML202Y/CML395Y/CLYN261 & 4.70 & 3.18 \\
4 & CML202Y/CML395Y/CML451Y & 4.82 & 3.33 \\
30 & CML202/CML395/CML445Y & 4.57 & 3.2 \\
31 & CML202/CML395/CKL05003 & 3.19 & 3.02 \\
LSD(0.05) & & & \\
\hline
\end{tabular}

TABLE 7. T-test results for yield and MSV severity of the white and yellow tester maize conversions

\begin{tabular}{llcccc}
\hline Trait & Group & d.f. & Mean & Variance & P-value \\
\hline Yield & CML202/CML395W & 10 & 4.85 & 5.85 & 0.57 \\
& CML202/CML395Y & & 5.57 & 3.29 & \\
& & & & 0.83 \\
& CML312/CML442W & 10 & 5.69 & 2.00 & \\
MSV & CML312/CML442Y & & 5.89 & 2.90 & 0.76 \\
& CML202/CML395W & 2 & 2.83 & 1.39 & \\
& CML202/CML395Y & & 2.50 & 0.50 & 0.90 \\
& CML312/CML442W & 2 & 2.67 & 0.00 & \\
\hline
\end{tabular}

be done in early generation for this type of population used. The findings suggest that both male and female parents used in this study are not suitable to induce MSV resistance in the three way crosses because they provided a limited contribution to MSV resistance. However, some lines that are MSV tolerant such as CML395 yellow (score of 1.85) and CML444 white (score of 1.91), in addition to
CML202 white, already known as resistant (Welz et al., 1998), can be combined with other lines having other desirable traits of interest to introgress the gene for MSV resistance.

Comparison between white and yellow maize conversions. The performances of the three-way hybrids (calculated based on their 
TABLE 8. T-test results for yield and MSV severity of the three way hybrids formed from white and corresponding yellow maize conversion

\begin{tabular}{llcccc}
\hline Trait & Group & d.f. & Mean & Variance & P-value \\
\hline Yield & CML202W/CML395W & 21 & 5.72 & 1.07 & 0.65 \\
& CML202Y/CML395Y & & 5.56 & 0.41 & \\
& & & & 0.15 \\
& CML312W/CML442W & 22 & 6.27 & 0.71 & \\
& CML312Y/CML442Y & & 6.14 & 0.71 & 0.18 \\
MSV & CML202W/CML395W & 21 & 1.13 & 0.01 & \\
& CML202Y/CML395Y & & 1.07 & 0.01 & 0.15 \\
& & & 1.17 & 0.03 & \\
& CML312W/CML442W & 22 & 1.08 & 0.01 & \\
& CML312Y/CML442Y & & & &
\end{tabular}

TABLE 9. Yield, MSV resistance and other traits of the three way maize hybrids based on their female tester parents

\begin{tabular}{lcrrrrrrr}
\hline Testers & \multicolumn{7}{c}{ Mean of the three way crosses } \\
\cline { 2 - 9 } & $\begin{array}{c}\text { Yield } \\
\left(\mathrm{t} \mathrm{ha}^{-1}\right)\end{array}$ & $\begin{array}{r}\text { TLB } \\
(1-5)\end{array}$ & $\begin{array}{c}\text { GLS } \\
(1-5)\end{array}$ & $\begin{array}{c}\text { P H } \\
(1-5)\end{array}$ & $\begin{array}{r}\text { EH } \\
(1-5)\end{array}$ & $\begin{array}{c}\text { E T } \\
(1-5)\end{array}$ & $\begin{array}{c}\text { AD } \\
\text { (days) }\end{array}$ & $\begin{array}{c}\text { SD } \\
\text { (days) }\end{array}$ \\
\hline CML202/CML395 & 5.72 & 2.04 & 1.65 & 177.39 & 81.14 & 2.4 & 67.18 & 68.72 \\
CML202Y/CML395Y & 5.56 & 2.01 & 1.6 & 158.88 & 67.57 & 2.45 & 64.92 & 65.9 \\
CML312/CML442 & 6.27 & 2.16 & 1.58 & 169.6 & 73.26 & 3.15 & 66.3 & 67.57 \\
CML312Y/CML442Y & 6.14 & 2.1 & 1.59 & 175.15 & 75.77 & 3.09 & 65.88 & 66.93 \\
LSD(P<0.05) & 1.53 & 0.59 & 0.29 & 23.59 & 16.81 & 0.58 & 3.68 & 4.14 \\
\hline
\end{tabular}

MSV = Maize streak virus, TLB = Turcicum leaf blight, GLS = Gray leaf spot, $\mathrm{PH}=$ Plant height, $\mathrm{EH}=$ ear height, $\mathrm{AD}=$ anthesis days, $\mathrm{SD}=$ silking days

females parent conversions from which they were generated) for yield, MSV and other agronomic traits assessed in this study were quite similar (Tables 7 and 8). This implies that, white testers and corresponding yellow conversions are genetically similar in terms of resistance to MSV, yield and other trait performance to the progenies. Therefore, since there is no genetic penalty, a maize breeder could convert white maize into yellow maize and develop new yellow maize varieties rich in provitamin A content, useful in combating malnutrition.

Among the five top three-way hybrids resistant to MSV, three of them were obtained from the inbred line CKDHL0500 (Table 5), implying that this inbred line is a fair combiner for MSV resistance $(\mathrm{GCA}=-0.88)$; while the yellow line CML451 is the worst combiner $(\mathrm{GCA}=0.80)$. This worst general combiner CML451 (yellow), was further confirmed by having two three-way hybrids among the 5 
TABLE 10. Estimate of GCA and SCA for maize grain yield (and MSV resistance) across locations

\begin{tabular}{|c|c|c|c|c|c|}
\hline \multirow[t]{3}{*}{ Lines } & \multicolumn{4}{|c|}{ Testers } & \multirow[t]{3}{*}{ GCA line } \\
\hline & $\begin{array}{l}\text { CML202/ } \\
\text { CML395 }\end{array}$ & $\begin{array}{l}\text { CML202Y/ } \\
\text { CML395Y }\end{array}$ & $\begin{array}{l}\text { CML312/ } \\
\text { CML442 }\end{array}$ & $\begin{array}{l}\text { CML312Y/ } \\
\text { CML442Y }\end{array}$ & \\
\hline & \multicolumn{4}{|c|}{------- SCA effects -------} & \\
\hline DTPCY9-F46 & $0.09(-0.18)$ & $0.40(0.20)$ & $1.073(0.21)$ & $-1.16(-0.03)$ & $-0.57(0.45)$ \\
\hline CLYN261 & $0.47(0.75)$ & $-1.07(0.40)$ & $-0.40(-0.49)$ & $-0.46(-0.46)$ & $0.2(-0.08)$ \\
\hline CML451Y & $1.35(-0.37)$ & $-0.7(-0.32)$ & $-0.01(-0.54)$ & $-0.26(0.5)$ & $-0.05(0.8)$ \\
\hline CML444Y & $0.97(0.04)$ & $0.11(0.18)$ & $0.52(-0.34)$ & $-0.79(0.6)$ & $0.28(-0.19)$ \\
\hline CML445Y & $0.02(-0.25)$ & $0.56(0.22)$ & $0.25(-0.008)$ & $-0.38(0.08)$ & $-0.48(0.23)$ \\
\hline CKL05003 & $-0.66(0.10)$ & $-0.26(0.5)$ & $-0.41(0.23)$ & $0.50(-0.56)$ & $-0.61(0.08)$ \\
\hline ZM523A-16 & $-1.91(0.07)$ & $-0.15(0.03)$ & $0.98(-0.8)$ & $1.19(0.23)$ & $-0.37(0.11)$ \\
\hline CKDHL0159 & $0.53(-0.62)$ & $0.47(-0.17)$ & $0.10(0.32)$ & $-0.48(0.27)$ & $0.12(-0.26)$ \\
\hline CKDHL0500 & $-0.21(0.48)$ & $0.29(0.17)$ & $-1.07(0.15)$ & $0.81(-0.45)$ & $0.2(-0.88)$ \\
\hline CML444 & $-0.41(0.12)$ & $-0.17(-0.54)$ & $0.35(0.19)$ & $-0.23(-0.49)$ & $1.01(-0.03)$ \\
\hline CML445 & $-0.39(-0.9)$ & $0.52(-0.68)$ & $-0.18(1.02)$ & $0.74(0.43)$ & $0.01(0.06)$ \\
\hline CLRC034 & $0.14(0.77)$ & - & $-1.19(0.04)$ & $0.52(-0.13)$ & $0.35(-0.37)$ \\
\hline GCA tester & $0.33(0.01)$ & $-0.21(0.00)$ & $0.20(0.18)$ & $-0.35(-0.19)$ & \\
\hline
\end{tabular}

The figures in parenthesis (...) mean GCA and SCA for MSV resistance; while the other figures mean GCA and SCA for yield

most susceptible ones. Comparison of reaction to MSV inoculation results (Table 7) between conversions (i.e., CML202 white versus CML202 yellow, CML312 white versus CML312 yellow, CML395 white versus CML395 yellow, CML442 white versus CML442 yellow, CML444 white versus CML444 yellow, CML445 white versus CML445 yellow), indicated that tolerance to MSV is not consistent with grain colour. This suggests that the gene controlling the MSV tolerance is not associated with the gene for grain colour of maize; and they might be inherited independently. However, the gene controlling the MSV resistance (Kyetere et al., 1999; Welz et al., 1998; Mawere et al., 2006, Gichuru, 2013; Mafu, 2013) and that controlling the grain colour (Xie et al., 2013) are all located on chromosome 1. As Pernet et al. (1999) reported, for different populations, a major QTL for MSV resistance is stable across the time and does not change from one population to another. This QTL for MSV resistance was identified on the short arm of chromosome 1 and designated as msvl.

Likewise, for yield the difference in combining ability seems not to be based on grain colour. Indeed, among the female parents, the good combining ability is based on heterotic group. The parents from heterotic group A (positive GCA) contributed most for yield compared to those of heterotic group B (negative GCA) (Table 10). However, among the male parents, the white inbred lines contributed most for grain yield compared to their yellow conversions (Table 10). The yellow inbred lines, CLRC034 and CLYN261 (not having their white corresponding conversions), appear to be good general combiners for yield. Moreover, among the six top crosses with high SCA, 50\% are yellow and $50 \%$ are white. The similarity observed in 
yield heritability was not clearly predicted by the inbred lines performance in yield. Indeed, among the white and yellow inbred lines conversions evaluated, the mean of yield from yellow lines were higher than their corresponding white lines conversions (Table 5).

In general, lack of significant difference between white and corresponding yellow maize conversion, implies that there is no loss in MSV resistance and yield performance while converting white to yellow maize.

\section{CONCLUSION}

Among inbred lines, in addition to the CML202 (white) already known as a source of MSV resistance, lines CML395 (yellow), CML444 (white), CML445 (white) and CML312-SR (white) also show tolerance to the disease and should be considered as source of MSV resistance. The gene for resistance to MSV seems not to be associated with the gene controlling the color in maize. The heritability of MSV resistance is not based on the colour of the genotypes; rather on the heterotic group of the germplasm used in the study. Heritability for resistance to MSV is low, indicating that for this particular germplasm used a big number of crosses or generations is required to be able to transmit the MSV resistance from parents to the progenies; while the yield heritability was also low due the variation of environments and the fact that it is a quantitative trait. The female (single crosses) parents used in the crosses had higher contribution to variation in the resistance to the MSV and yield performance than the inbred line male parents.

The inbred lines, CKDHL0500, CLRC034, CKDHL0159 and CML444 (yellow) bear a negative GCA effects for MSV resistance indicating that they contribute a lot to MSV resistance. These lines, after confirmation of their GCA effects, should be used as useful MSV resistant source lines to generate hybrid cultivars resistant to MSV. Yellow testers can be used in pro-vitamin A maize breeding since they are generally equal to their corresponding white conversions in terms of resistance to MSV and yield performance.

\section{ACKNOWLEDGMENT}

The authors thank Intra ACP Academic Mobility and the Regional Universities Forum for Capacity Building in Agriculture (RUFORUM) for funding this work. Makerere University and the National Crop Resources Research Institute (NaCRRI) are thanked for hosting the experiments. Mr. Alladassi Boris M.E. and Mr. Frejus Ariel Kpedetin Sodedji provided scientific contribution to generation of this manuscript.

\section{REFERENCES}

Aminu, D. and Izge, A.U. 2012. Heritability and Correlation Estimates in Maize (Zea mays L.) Under Drought Conditions in Northern Guinea and Sudan Savannas of Nigeria. World Journal of Agricultural Sciences 8(6):598-602.

Awata, L.A.O. 2012. Combining ability for multiple resistance to Turcicum leaf blight (Exserohilum turcicum) and Maize streak virus disease. MSc dissertation, Makerere University, Kampala, Uganda. 92pp.

Betr'an, F.J., Isakeit, T. and Odvody, G. 2002. Aflatoxin accumulation of white and yellow maize inbreds in diallel crosses. Crop Science 42:1894-1901.

Efron, Y., Kim, S.K., Fajemisin, J.M., Mareck, J.H., Tang, C.Y., Dabrowski, Z.T. and Buddenhagen, I.W. 1989. Breeding for resistance to Maize streak virus: A multidisciplinary team approach1. Plant Breeding 103(1):1-36.

George, A. 2007. Principles of Plant Genetics and Breeding. Malden, USA. 585pp.

Gichuru, L.N. 2013. Breeding investigations on utility of Maize streak virus resistant germplasm for hybrid development in the Tropics. Doctoral dissertation, University 
of KwaZulu-Natal Pietermaritzburg, South Africa. 243pp.

Gichuru, L., Njoroge, K., Ininda, J. and Peter, L. 2011. Combining ability of grain yield and agronomic traits in diverse maize lines with maize streak virus resistance for Eastern Africa region. Agriculture and Biology Journal of North America 2:432439.

Kandianis, C.B., Stevens, R., Liu, W., Palacios, N., Montgomery, K., Pixley, K. and Rocheford, T. 2013. Genetic architecture controlling variation in grain carotenoid composition and concentrations in two maize populations. Theoretical and Applied Genetics 126:2879-2895.

Kristin, C., Alexander, E.L., Brenda, F.O., Huihui, L., Edward, S.B., Torbert, R. and Michael, A.G. 2013. Genetic analysis of visually scored orange kernel color in maize. Crop Sciences 53:189-200.

Kwemoi, D.B. 2010. Characterisation of a diverse set of maize germplasm for resistance to infection by Aspergillus flavus. MSc. dissertation, Makerere University, Kampala, Uganda. 102pp.

Kyetere, D.T., Ming, R., McMullen, M.D., Pratt, R.C., Brewbaker, J. and Musket, T. 1999. Genetic analysis of tolerance to maize streak virus in maize. Genome 42:20-26

Mafu, N.F. 2013. Marker-assisted selection for maize streak virus resistance and concomitant conventional selection for downy mildew resistance in a maize population. MSc. Thesis, University of KwaZulu-Natal, South Africa. 177pp.

Mawere, S., Vincent, V., De Meyer, J. and Pixley, K.V. 2006. Resistance of four inbred maize lines to inoculation with 20 isolates of Maize streak virus from Zimbabwe. Plant disease 90:1485-1489.

Melanie, L.E. 2006. Genotypic and phenotypic characterization of response to Aflatoxin and secondary traits in maize. $\mathrm{PhD}$ Dissertation, Texas A\&M University, USA. 192 pp.
Nilsa, A.B.P. 2000. Eight decades of maize streak virus research. Virus Research (71): 107-121.

Nilsa, A.B., Olojede, S.O. and Buddenhagen, I.W. 1998. Effect of maize streak virus disease on the growth and yield of maize as influenced by varietal resistance levels and plant stage at time of challenge. Euphytica 01/1998; 101(3):307-317.

Okoboi, G., Muwanga, J. and Mwebaze, T. 2012. Use of improved inputs and its effect on maize yield and profit in Uganda, Makerere University, Kampala, Uganda. $14 \mathrm{pp}$.

Olakojo, S.A. and Olaoye, G. 2011. Correlation and heritability estimates of maize agronomic traits for yield improvement and Striga asiatica (L.) Kuntze tolerance. Plant Sciences (5):364-369.

Oppong, A. 2013. Development of topcross hybrid maize (Zea mays L.) for yield and resistance to maize streak viruse disease. Doctorate Dissertation. Univerisity of Ghana. Legon, Ghana. 208pp.

Pernet, A., Hoisington, D., Dintinger, J., Jewell, D., Jiang, C., Khairallah, M. and De Leon, D.G. 1999. Genetic mapping of maize streak virus resistance from the Mascarene source. II. Resistance in line CIRAD390 and stability across germplasm. Theoretical and Applied Genetics 99(3-4):540-553.

Richards, R.A. 2006. Physiological traits used in the breeding of new cultivars for waterscarce environments. Agricultural Water Management 80(1):197-211.

Tefera, T., Mugo, S., Beyene, Y., Karaya, H. and Tende, R. 2011. Grain yield, stem borer and disease resistance of new maize hybrids in Kenya. African Journal of Biotechnology 10(23):4777-4783.

Uganda Bureau of Statistics (UBOS). 2013. Statistical abstract, Kampala, Uganda, 2013, 264pp.

Welz, H.G., Schechert, A., Pernet, A., Pixley, K.V. and Geiger, H.H. 1998. A gene for 
resistance to the maize streak virus in the African CIMMYT maize inbred line CML202. Molecular Breeding 4(2):147154.

Xie, C., Weng, J., Liu, W., Zou, C., Hao, Z., Liu, W., Zou, C.,Hao, Z., Li, W., Li, M.,
Guo X., Zhang, G., Xu, Y., Li, X. and Zhang, S. 2013. Zea mays (L.) P1 locus for cob glume color identified as a postdomestication selection target with an effect on temperate maize genomes. The Crop Journal 1(1):15-24. 